\title{
Peran Accounting Information Bagi Investor Islami
}

Jurnal Akuntansi Terapan Indonesia Vol 3 No 2 Hal 80-93 October 2020

\section{Affiliation:}

Universitas Muhammadiyah Jember, Indonesia

\section{*Correspondence:}

rendymirwanaspirandi@unmuhjember ac.id

This Article is Avalilable in: https://journal.umy.ac.id/index. php/jati/article/view/9564

\section{DOI:}

https://doi.org/10.18196/jati.030229

\section{Citation:}

Aspirandi, R., Setianingsih, W., Ramadhana, R., \& Maftahah, R. (2020). Peran Accounting Information Bagi Investor Islami. Jati: Jurnal Akuntansi Terapan Indonesia, 3(2), 8093.

\section{Article History}

Received:

18 Agustus 2020

Reviewed:

12 September 2020

Revised:

21 October 2020

Accepted:

02 November 2020

Topic Article:

Akuntansi Keperilakuan

\author{
Rendy Mirwan Aspirandi*1, Wahyu Eko Setianingsih², Ramadhana ${ }^{3}$, \\ Riif Maftahah ${ }^{4}$
}

\begin{abstract}
:
Kustodian Sentral Efek Indonesia (KSEI) reported growth in the number of investors in Indonesia reached $44.06 \%$. In fact, the growth in the number of investors is not proportional to the growth in the IHSG performance. The purpose of this study was to analyze the role of accounting information in making investment decisions. Frequency distribution analysis was used in this study. The analysis shows that the primary reason for investors in making investment decisions is an analysis of the company's current financial statements, an indicator of Accounting Information variables. Accounting Information variable analysis found that Investors registered at GI BEI Muhammadiyah University of Jember considered Accounting Information more than other places. Consequently, the following are investors who are more concerned with Accounting Information compared to their peers: 21-30 years old investors, investors with a bachelor's degree in education, and investors who have investment experience for 4-6 years. Also, Islamic investors considered Accounting Information at $63.44 \%$.
\end{abstract}

Keywords: Islamic Investor, Neutral Information, Accounting Information, Self Image/Firm-Image Coincidence, Classic.

\section{Abstrak:}

Kustodian Sentral Efek Indonesia (KSEI) melaporkan bahwa pertumbuhan jumlah investor di Indonesia mencapai 44,06\%. Pada kenyataannya pertumbuhan jumlah investor tidak sebanding dengan pertumbuhan kinerja IHSG. Tujuan penelitian ini adalah menganalisis peran Accounting Information terhadap pengambilan keputusan investasi. Metode yang digunakan adalah analisis distribusi frekuensi. Hasil analisis menunjukkan bahwa peringkat pertama dalam kasus sangat dipertimbangan investor dalam mengambil keputusan investasi adalah Analisis terhadap laporan keuangan perusahaan saat ini yang merupakan indikator variabel Accounting Information. Analisis variabel Accounting Information ditemukan bahwa Investor yang terdaftar di GI BEI Universitas Muhammadiyah Jember lebih mempertimbangkan Accounting Information dibandingkan dengan Investor yang terdaftar di tempat lainnya. Investor berusia 21-30 tahun ditemukan lebih mempertimbangkan Accounting Information dibandingkan investor lainnya. Investor bertingkat pendidikan S1 lebih mempertimbangkan Accounting Information dibandingkan yang lainnya. Investor yang memiliki pengalaman berinvestasi selama 4-6 tahun lebih mempertimbangkan Accounting Information dibandingkan investor lainnya. Investor islami memiliki proporsi 63,44\% mempertimbangkan Accounting Information.

Kata Kunci: Investor Islami, Neutral Information, Accounting Information, Self Image/Firm-Image Coincidence, Classic. 


\section{PENDAHULUAN}

Investor di pasar modal Indonesia terus mengalami peningkatan seiring berjalannya waktu. "Kustodian Sentral Efek Indonesia (KSEI) melaporkan bahwa pertumbuhan jumlah investor di Indonesia mencapai 44,06\%" (www.market.bisnis.com). Pertumbuhan jumlah investor tersebut dapat dilihat dari bertambahnya jumlah Single Investor Identification (SID). SID merupakan nomor induk setiap investor yang ada di pasar modal Indonesia. Salain pertumbuhan jumlah investor yang menjadi penanda terus tumbuhnya pasar modal Indonesia, Indeks Harga Saham Gabungan (IHSG) juga turut menjadi patokan. IHSC dari tahun 2014 sampai 2018 terus mengalami petumbuhan. Pertumbuhan IHSG dapat dilihat pada Tabel 1 berikut.

Tabel 1. Pertumbuhan IHSG 10 Tahun Terakhir

\begin{tabular}{crrr}
\hline Tahun & IHSG Akhir Tahun & Perolehan Tahunan & Akumulasi Perolehan \\
\hline 2008 & 1355.41 & nilai awal & nilai awal \\
2009 & 2534.36 & $86.98 \%$ & $86.98 \%$ \\
2010 & 3703.51 & $46.13 \%$ & $173.24 \%$ \\
2011 & 3821.99 & $3.20 \%$ & $181.98 \%$ \\
2012 & 4316.69 & $12.94 \%$ & $218.48 \%$ \\
2013 & 4274.18 & $-0.98 \%$ & $215.34 \%$ \\
2014 & 5226.95 & $22.29 \%$ & $285.64 \%$ \\
2015 & 4593.01 & $-12.13 \%$ & $238.86 \%$ \\
2016 & 5296.71 & $15.32 \%$ & $290.78 \%$ \\
2017 & 6355.65 & $19.99 \%$ & $368.91 \%$ \\
2018 & 6194.5 & $-2.54 \%$ & $357.02 \%$ \\
\multicolumn{4}{c}{ Kinerja IHSG disetahunkan } \\
\end{tabular}

Sumber: Data diolah

Pada Tabel 1 menunjukkan bahwa pertumbuhan IHSG hanya 16,41\% selama 10 tahun. Pada kenyataannya pertumbuhan jumlah investor mencapai 44,06\%. Hal ini menunjukkan bahwa masih banyak investor-investor baru yang takut untuk merealisasikan investasinya di Pasar Modal Indonesia. Jadi, kebanyakan SID yang terbentuk hanya SID yang tidur tanpa ada aktivitas investasi. Ketakutan para investor baru ini dipengaruhi oleh banyak factor, antaralain: Neutral Information, Accounting Information, Self Image/Firm-Image Coincidence, Classic, Social Relevance, Advocate Recommendation, dan Personal Financial Need (Christanti et al., 2011).

Neutral Information ( $\mathrm{Ne}$ ) adalah informasi berasal dari luar yang menunjukkan gambaran agar informasi-informasi yang didapat tidak berat sebelah, informasi ini mencakup ulasan dan informasi dari media tentang keuangan maupun keadaan ekonomi yang berhubungan dengan kegiatan investasi yang meliputi informasi tentang keadaa atau kondisi saat ini dengan perkembangan investasi yang ada serta hal-hal lain yang berhubungan dengan investasi dan keuangan, pemberitaan atau atau ulasan dimedia umum, perubahan harga saham, ulasan dari analisis keuangan yang dipublikasikan dimedia, dan indikator ekonomi. Accounting Information (Ac) atau yang sering disebut dengan informasi akuntansi merupakan informasi yang dihasilkan oleh data-data akuntansi baik bersifat kuantitatif maupun kualitatif. Classic (Cl) merupakan kemampuan investor menentukan kriteria pada dasar ekonomis dari prilaku investor, meliputi informasi tentang 
deviden yang diharapkan, harga saham pada pembukaan, konsekuensi pajak yang harus ditanggung dan kemampuan untuk memperkecil risiko. (Anna et. al.). Self Image/Firm-Image Coincidence (Se) merupakan informasi yang berhubungan dengan penilaian terhadap perusahaan, meliputi informasi tentang reputasi perusahaan, posisi perusahaan pada industri yaitu termasuk market leader atau market follower, new comers, perkiraan produk dan pelayanan perusahaan, mengetahui etika-etika perusahaan, nilai saham perusahaan pada waktu yang lalu (Nagy dan Obenberger, 1994).

Social Relevance (So) menyangkut informasi keberadaan saham perusahaan di bursa saham dan tanggung jawab sosial perusahaan, yang meliputi informasi tentang posisi saham dalam saham-saham yang terdaftar pada bursa saham termasuk saham blue chip atau second liner, jenis investasi yang beroperasi di area lokal, jenis investasi yang beroperasi di area internasional, dan bentuk kepedulian perusahaan terhadap lingkungan (Corporate Social Responsibility) (Nagy dan Obenberger, 1994). Advocate Recommendation (Ad) merupakan sumber informasi dapat membangun gagasan dan pemahaman berdasarkan rekomendasi yang telah diberikan dengan memperhatikan kepentingan tetap dalam hasil pada kegiatan pokok investor, hal ini juga diungkapkan oleh Toral (2002) bahwa investor dalam pemilihan investasi membutuhkan tenaga profesional sehingga tidak ada kecemasan dalam memilih investasi di saat keadaan pasar sedang lesu, informasi tersebut meliputi rekomendasi dari broker, rekomendasi dari teman, dan pendapat dari keluarga (Nagy dan Obenberger, 1994). Personal Financial Needs (Pe) jenis informasi ini didapat berdasarkan pengalaman investor dalam melihat nilai investasi dan perhitungan pada pengeluaran konsumsi sebagai seorang yang sungguh indipenden, yang meliputi informasi tentang target hasil dari investasi untuk memenuhi keuangan pribadi, estimasi dana untuk investasi, keinginan diversifikasi, melihat kembali kinerja portofolio saham yang dimiliki di masa yang lalu, melihat alternatif investasi lain selain yang telah dimiliki dengan melakukan perbandingan alternatif investasi selain saham, misalnya obligasi, emas, deposito, dan lainlain (Nagy dan Obenberger, 1994).

Seorang investor rasional seharusnya memiliki dasar dalam mengambil keputusan investasi di pasar modal. Salah satu dasar dalam pengambilan keputusan investasi adalah Accounting Information. Investor islami lebih mengutamakan aktivitas perusahaan yang berdasarkan konsep-konsep keislaman (hukum islam). Hukum islam ini dapat dikaitkan dengan beberapa hal, seperti: produk dan jasa perusahaan harus halal, total hutang yang berbasis bunga dibandingkan dengan total ekuitas tidak lebih dari 82\% (hutang berbasis bunga dibandingkan dengan total ekuitas tidak lebih dari 45\%:55\%), dan total pendapatan bunga dan pendapatan tidak halal lainnya dibandingkan dengan total pendapatan tidak lebih dari 10\% (DSN MUI No. 40 Tahun 2003).

Penelitian yang telah dilakukan oleh (Merikas et al., 2011) menemukan bahwa Accounting Information menjadi indikator utama yang mempengaruhi perilaku investor di Greek Stock Exchange. (Al-Tamimi, 2014) menemukan bahwa Accounting Information sangat mempengaruhi perilaku investor di pasar modal. Selain itu, penelitian yang dilakukan oleh (Christanti et al., 2011) menyatakan bahwa Accounting Information sangat dipertimbangkan oleh para investor sebelum mengambil keputusan investasi. Namun, penelitian yang dilakukan oleh (Obamuyi, 2013) menemukan bahwa Accounting Information tidak mempengaruhi keputusan investor ketika dilihat pada keadaan tingkat pendapatan 
investor di Nigeria. Perbedaan hasil penelitian ini menunjukkan bahwa penelitian Peran Accounting Information Bagi Investor Islami masih perlu dan penting untuk dilakukan mengingat Accounting Information merupakan produk akuntansi keuangan satu-satunya yang dapat menjadi suatu rujukan bagi investor. Sehingga penelitian ini memiliki tujuan untuk mengetahui dan menganalisis landasan pengambilan keputusan investasi Accounting Information pada investor secara umum dan investor islami di Kabupaten Jember.

\section{METODE PENELITIAN}

Neutral Information ( $\mathrm{Ne}$ ), memiliki 3 buah indikator dan dinilai dengan kuesioner berskala Likert $1 \mathrm{~s} / \mathrm{d}$ 3. Accounting Information (Ac) memiliki 4 buah indikator dan dinilai dengan kuesioner berskala Likert $1 \mathrm{~s} / \mathrm{d} 3$. Classic $(\mathrm{Cl})$ memiliki 3 buah indikator dan dinilai dengan kuesioner berskala Likert $1 \mathrm{~s} / \mathrm{d} 3$. Self Image/Firm-image Coincidence (Se) memiliki 4 buah indikator dan dinilai dengan kuesioner berskala Likert $1 \mathrm{~s} / \mathrm{d}$ 3. Social Relevance (So) memiliki 2 buah indikator dan dinilai dengan kuesioner berskala Likert $1 \mathrm{~s} / \mathrm{d} 3$. Advocate Recommendation (Ad) memiliki 3 buah indikatior dan dinilai dengan kuesioner berskala Likert $1 \mathrm{~s} / \mathrm{d}$ 3. Personal Financial Needs (Pe) memiliki 4 buah indikator dan dinilai dengan kuesioner berskala Likert $1 \mathrm{~s} / \mathrm{d}$ 3. Skala 1 Tidak Dipertimbangkan, Skala 2 Dipertimbangkan, dan Skala 3 Sangat Dipertimbangkan. Skala penilaian ini berdasarkan skala yang dipergunakan oleh (Merikas et al., 2011) dan (Christanti et al., 2011) dengan beberapa penyesuaian.

Populasi dalam penelitian ini adalah seluruh investor yang terdaftar di Galeri Investasi Bursa Efek Indonesia yang berada di Kabupaten Jember, yaitu: GI BEI Universitas Muhammadiyah Jember, STIE Mandala Jember dan GI BEI Universitas Jember. Alasan pemilihan Kabupaten Jember adalah investor di Kabupaten Jember dirasa mampu mewakili keseluruhan karakteristik investor di BEl. Pemilihan sampel dalam penelitian ini menggunakan teknik Random Sampling. Kuesioner akan dirancang dalam bentuk kuesioner elektronik menggunakan fasilitas Google Forms. Perhitungan jumlah sampel dalam penelitian ini menggunakan metode Slovin sebagai berikut:

$$
\begin{gathered}
n=\frac{N}{1+N(e)^{2}} \\
n=\frac{1168}{1+1168(0,1)^{2}} \\
n=\frac{1168}{12,68}=92
\end{gathered}
$$

Keterangan :

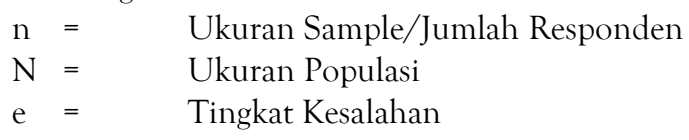

Pada hitungan metode slovin diatas didapatkan populasi penelitian sebnayak 1168 investor dari GI BEI Universitas Muhammadiyah Jember, STIE Mandala Jember dan GI BEI Universitas Jember. Selanjutnya populasi menjadi dasar dalam perhitungan sampel berdasarkan metode slovin yang ditemukan sebanyak 92 sampel investor.

Uji kualitas data penelitian menggunakan uji validitas dan reliabilitas. Analisis data menggunakan analisis distribusi frekuensi dan analisis crosstab yang dibantu dengan software SPSS 21. Analisis distribusi frekuensi digunakan karena penelitian ini pada dasarnya menganalisis pengambilan keputusan investasi dari beberapa investor, yang satu sama lain 
akan memiliki pandangan yang berbeda-beda.m Oleh karena itu, penelitian ini akan menganalisis besarnya variabel pengambilan keputusan investasi yang terbanyak.

\section{HASIL DAN PEMBAHASAN}

Kuesioner yang disebarkan kepada responden selama 30 hari melalui media elektronik Google Form menghasilkan 102 tanggapan dan menghapus 9 tanggapan dengan data isian yang tidak lengkap sehingga total tanggapan yang dapat diolah sebanyak 93 tanggapan. Uji validitas data menghasilkan semua indikator Variabel $\mathrm{Ne}$ (Neutral Information), Ac (Accounting Information), Cl (Classic), Se (Self Image/Firm-Image Coincidence), So (Social Relevance), Ad (Advocate Recommendation), dan Pe (Personal Financial Need) berkorelasi signifkan terhadap total konstruk Variabel Ne (Neutral Information), Ac (Accounting Information), Cl (Classic), Se (Self Image/Firm-Image Coincidence), So (Social Relevance), Ad (Advocate Recommendation), dan Pe (Personal Financial Need).

Uji Reliabilitas data menghasilkan nilai yang tergolong rendah. Uji reliabilitas data pada dasarnya digunakan untuk menguji konsistensi jawaban responden, jadi jawaban yang sangat melenceng dari kebanyakan jawaban responden akan dianggap sebagai outlier dan menyebabkan data tidak reliabel (Ghozali, 2016). Namun, ketika kita melihat dasar dari penelitian ini dilakukan adalah untuk melihat preferensi para responden yang terdiri dari investor dalam mengambil keputusan investasinya. Jadi sudah wajar apabila jawaban responden bervariasi, karena preferensi masing-masing investor akan berbeda dan tidak dapat disama ratakan.

Pada Tabel 2 berikut akan disajikan ringkasan mengenai frekuensi variabel yang sangat dipertimbangkan oleh investor dalam mengambil keputusan berinvestasi di pasar modal.

Tabel 2. Frekuensi Variabel yang Sangat Dipertimbangkan dalam Keputusan Investasi

\begin{tabular}{|c|c|c|c|c|}
\hline Kategori & Peringkat & Variabel & Jumlah & Persentase \\
\hline Ac & 1 & $\begin{array}{l}\text { Analisis terhadap laporan keuangan perusahaan } \\
\text { saat ini }\end{array}$ & 86 & $92,47 \%$ \\
\hline $\mathrm{Pe}$ & 2 & Estimasi dana untuk investasi & 85 & $91,39 \%$ \\
\hline Ac & 3 & Pendapatan perusahaan yang diharapkan & 84 & $90,32 \%$ \\
\hline Se & 4 & Harga saham sebelumnya & 83 & $89,25 \%$ \\
\hline $\mathrm{Ne}$ & 5 & $\begin{array}{l}\text { Perubahan harga dari saham perusahaan } \\
\text { baru-baru ini }\end{array}$ & 81 & $87,09 \%$ \\
\hline $\mathrm{Cl}$ & 6 & Harga saham pembukaan setiap harinya & 76 & $81,72 \%$ \\
\hline $\mathrm{Ad}$ & 7 & Rekomendasi saham dari teman atau teman kerja & 76 & $81,72 \%$ \\
\hline $\mathrm{Ne}$ & 8 & Kondisi perekonomian saat ini secara umum & 73 & $78,49 \%$ \\
\hline $\mathrm{Cl}$ & 9 & Besar dividen yang diharapkan untuk didapatkan & 73 & $78,49 \%$ \\
\hline $\mathrm{Ne}$ & 10 & $\begin{array}{l}\text { Pemberitaan/ulasan di media massa/media } \\
\text { keuangan }\end{array}$ & 71 & $76,34 \%$ \\
\hline $\mathrm{Cl}$ & 11 & $\begin{array}{l}\text { Diversifikasi saham dalam portofolio } \\
\text { untuk memperkecil risiko kemungkinan kerugian } \\
\text { yang dialami }\end{array}$ & 67 & $72,04 \%$ \\
\hline $\mathrm{Pe}$ & 12 & $\begin{array}{l}\text { Kinerja portofolio saham yang dimiliki } \\
\text { di masa lalu }\end{array}$ & 66 & $70,97 \%$ \\
\hline $\mathrm{Ad}$ & 13 & Rekomendasi saham dari broker & 61 & $65,59 \%$ \\
\hline Se & 14 & Reputasi perusahaan & 58 & $62,37 \%$ \\
\hline $\mathrm{Pe}$ & 15 & $\begin{array}{l}\text { Target hasil investasi yang diinginkan untuk } \\
\text { memenuhi kebutuhan keuangan pribadi }\end{array}$ & 58 & $62,37 \%$ \\
\hline Ac & 16 & Kemampuan bursa saham saat ini & 52 & $55,91 \%$ \\
\hline So & 17 & Posisi saham dalam daftar bursa saham & 51 & $54,84 \%$ \\
\hline
\end{tabular}




\begin{tabular}{|c|c|c|c|c|}
\hline & & (bluechip, second liner) & & \\
\hline $\mathrm{Pe}$ & 18 & $\begin{array}{l}\text { Perbandingan alternatif investasi lain } \\
\text { (obligasi, emas, deposito, dll.) }\end{array}$ & 37 & $39,79 \%$ \\
\hline Se & 19 & $\begin{array}{l}\text { Posisi perusahaan dalam industri } \\
\text { (market leader, market follower, new comers, dll.) }\end{array}$ & 20 & $21,51 \%$ \\
\hline Se & 20 & Etika perusahaan & 17 & $18,28 \%$ \\
\hline Ac & 21 & Data dalam laporan/prospektus perusahaan & 14 & $15,05 \%$ \\
\hline So & 22 & $\begin{array}{l}\text { Bentuk kepedulian perusahaan terhadap } \\
\text { lingkungan (CSR) }\end{array}$ & 14 & $15,05 \%$ \\
\hline $\mathrm{Ad}$ & 23 & Rekomendasi saham dari pendapat keluarga & 8 & $8,60 \%$ \\
\hline
\end{tabular}

Sumber: Data diolah

Keterangan:

$\mathrm{Ne}$ : Neutral Information

Ac : Accounting Information

$\mathrm{Cl}$ : Classic

Se : Self Image/Firm-Image Coincidence
So : Social Relevance

Ad : Advocate Recommendation

Pe : Personal Financial Need

Pada Tabel 2 diketahui bahwa di peringkat pertama dalam kasus sangat dipertimbangan investor dalam mengambil keputusan investasi adalah Analisis terhadap laporan keuangan perusahaan saat ini yang dijawab oleh 86 (92,47\%) investor. Indikator Analisis terhadap laporan keuangan perusahaan saat ini adalah indikator dari Variable Accounting Information (Ac). Hasil ini membuktikan bahwa pada analisis karakteristik responden yang telah dibahas bahwa responden terbanyak terdiri dari para investor yang beragama islam. Investor beragama islam sudah pasti akan berpikir rasional dan mempertimbangkan kinerja keuangan perusahaan sebagai landasan untuk melakukan investasi. Jadi, investor islam tidak mengambil keputusan investasi secara gambling (untung-untungan), karena sifat gambling adalah sebagian dari riba. Seperti yang telah tersurat dalam Al Qur'an Surat Al Baqarah 275-276 yang artinya :

"Orang-orang yang memakan riba tidak dapat berdiri melainkan seperti berdirinya orang yang kemasukan setan karena (tekanan) penyakit gila. Yang demikian itu karena mereka berkata bahwa jual beli itu sama dengan riba. Padahal Allah telah menghalalkan jual beli dan mengharamkan riba. Barang siapa mendapatkan peringatan dari Tuhannya, lalu dia berhenti, maka apa yang telah diperolehnya dahulu menjadi miliknya, dan urusannya (terserah) kepada Allah. Barang siapa yang mengulangi (mengambil riba), maka mereka itu penghuni neraka, mereka kekal di dalamnya" (QS. Al Baqarah : 275).

"Allah memusnahkan riba dan menyuburkan sedekah. Allah tidak menyukai setiap orang yang tetap dalam kekafiran dan bergelimang dosa" (QS. Al Baqarah : 276).

Pada Surat Surat Al Baqarah 275-276 telah dijelaskan bahwa riba sangat dilarang keras dalam agama Islam. Investor yang memiliki landasan dalam pengambilan keputusan investasinya berarti investor tersebut juga telah memenuhi persyaratan halalnya suatu investasi saham, seperti Fatwa DSN-MUI No: 40/DSN-MUI/X/2003 tentang Pasar Modal dan Pedoman Umum Penerapan Prinsip Syariah di Bidang Pasar Modal Pasal 5 Nomor 2 mengenai Transaksi Yang Dilarang yang berbunyi Transaksi yang mengandung unsur dharar, gharar, riba, maisir, risywah, maksiat dan kezhaliman.

Tabel 3 akan menyajikan hasil dari analisis tabulasi silang (crosstab) antara variabel penelitian terhadap Asal Investor terdaftar sebagai investor di Bursa Efek Indonesia (BEI). 
Tabel 3. Analisis Crosstab Mengenai Asal Investor

\begin{tabular}{|c|c|c|c|c|}
\hline VARIABEL & KRITERIA & $\begin{array}{c}\text { GI BEI UNIVERSITAS } \\
\text { MUHAMMADIYAH } \\
\text { JEMBER }\end{array}$ & $\begin{array}{l}\text { GI BEI STIE } \\
\text { MANDALA } \\
\text { JEMBER } \\
\end{array}$ & $\begin{array}{c}\text { GI BEI } \\
\text { UNIVERSITAS } \\
\text { JEMBER }\end{array}$ \\
\hline \multirow[t]{3}{*}{$\mathrm{Ne}$} & $\begin{array}{l}\text { Tidak Dipertimbangkan } \\
\text { Kadang-Kadang }\end{array}$ & 6 & 21 & 5 \\
\hline & Dipertimbangkan & 10 & 3 & 9 \\
\hline & Sangat Dipertimbangkan & 104 & 51 & 74 \\
\hline \multirow[t]{3}{*}{ Ac } & $\begin{array}{l}\text { Tidak Dipertimbangkan } \\
\text { Kadang-Kadang }\end{array}$ & 26 & 31 & 26 \\
\hline & Dipertimbangkan & 27 & 10 & 16 \\
\hline & Sangat Dipertimbangkan & 107 & 59 & 70 \\
\hline \multirow[t]{3}{*}{$\mathrm{Cl}$} & $\begin{array}{l}\text { Tidak Dipertimbangkan } \\
\text { Kadang-Kadang }\end{array}$ & 11 & 9 & 7 \\
\hline & Dipertimbangkan & 21 & 5 & 10 \\
\hline & Sangat Dipertimbangkan & 88 & 61 & 67 \\
\hline \multirow[t]{3}{*}{$\mathrm{Se}$} & $\begin{array}{l}\text { Tidak Dipertimbangkan } \\
\text { Kadang-Kadang }\end{array}$ & 56 & 36 & 38 \\
\hline & Dipertimbangkan & 31 & 16 & 17 \\
\hline & Sangat Dipertimbangkan & 73 & 48 & 57 \\
\hline \multirow[t]{3}{*}{ So } & $\begin{array}{l}\text { Tidak Dipertimbangkan } \\
\text { Kadang-Kadang }\end{array}$ & 36 & 22 & 20 \\
\hline & Dipertimbangkan & 21 & 9 & 13 \\
\hline & Sangat Dipertimbangkan & 23 & 19 & 23 \\
\hline \multirow[t]{3}{*}{ Ad } & $\begin{array}{l}\text { Tidak Dipertimbangkan } \\
\text { Kadang-Kadang }\end{array}$ & 37 & 26 & 31 \\
\hline & Dipertimbangkan & 27 & 5 & 8 \\
\hline & Sangat Dipertimbangkan & 56 & 44 & 45 \\
\hline \multirow[t]{3}{*}{$\mathrm{Pe}$} & $\begin{array}{l}\text { Tidak Dipertimbangkan } \\
\text { Kadang-Kadang }\end{array}$ & 31 & 19 & 19 \\
\hline & Dipertimbangkan & 34 & 9 & 14 \\
\hline & Sangat Dipertimbangkan & 95 & 72 & 79 \\
\hline
\end{tabular}

Hasil pengolahan data pada Tabel 3 menunjukkan bahwa jawaban sangat dipertimbangkan pada variabel Ac (Accounting Information) dari Investor yang terdaftar di GI BEI Universitas Muhammadiyah Jember sebesar $66,88 \%$ dari total jawaban Variabel Ac, Investor yang terdaftar di GI BEI STIE Mandala Jember sebesar 59,00\% dari total jawaban Variabel Ac dan Investor yang terdaftar di GI BEI Universitas Jember sebesar 62,50\% dari total jawaban Variabel Ac. Hasil analisis lanjutan ini membuktikan bahwa Investor yang terdaftar di GI BEI Universitas Muhammadiyah Jember lebih mempertimbangkan Accounting Information atau Informasi Akuntansi dibandingkan dengan Investor yang terdaftar di GI BEI STIE Mandala Jember dan GI BEI Universitas Jember. Hal ini dapat dipengaruhi dengan Mitra Sekuritas yang dijalin oleh GI BEI Universitas Muhammadiyah Jember yaitu Kresna Sekuritas. Perwakilan dari Kresna Sekuritas setiap tahunnya mengunjungi para Investor GI BEI Universitas Muhammadiyah Jember untuk memberikan seminar/workshop mengenai perkembangan pasar modal dan perekonomian di Indonesia. Pada sesi khusus, perwakilan Kresna Sekuritas juga memberikan bekal pengetahuan mengenai cara melakukan analisis Fundamental berupa cara menggunakan informasi akuntansi dan analisis Teknikal kepada para Investor GI BEI Universitas Muhammadiyah 
Jember. Bekal ilmu ini pada kenyataannya sangat dibutuhkan oleh para Investor dalam memberikan landasan pengambilan keputusan investasi. Hal ini diperkuat dengan karakteristik penanaman iman kepada para Investor di GI BEI Universitas Muhammadiyah Jember bahwa berinvestasi tidak hanya mengenai seberapa besar kita mendapatkan keuntungan dalam jangka pendek, tetapi para investor diberikan pendalaman iman dan takwa menganai kegiatan investasi yang sebenarnya adalah mengambil keputusan investasi dengan mengetahui keadaan fundamental perusahaan yang akan dibeli. Satu-satunya cara kita mengetahui keadaan perusahaan yang sahamnya akan kita beli adalah hanya dengan menggunakan informasi akuntansi sebagai landasan fundamental dalam menilai kinerja perusahaan masa lalu, saat ini dan masa depan.

Tabel 4 merupakan hasil analisis crosstab antara jenis kelamin dan tujuh varibel penelitian. Analisis dihasilkan oleh SPSS 21.

Tabel 4. Analisis Crosstab Mengenai Jenis Kelamin

\begin{tabular}{clcc}
\hline VARIABEL & \multicolumn{1}{c}{ KRITERIA } & LAKI-LAKI & PEREMPUAN \\
\hline \multirow{2}{*}{ Ne } & Tidak Dipertimbangkan & 11 & 21 \\
& Kadang-Kadang Dipertimbangkan & 6 & 16 \\
& Sangat Dipertimbangkan & 127 & 98 \\
Ac & Tidak Dipertimbangkan & 41 & 42 \\
& Kadang-Kadang Dipertimbangkan & 28 & 25 \\
& Sangat Dipertimbangkan & 123 & 113 \\
$\mathrm{Cl}$ & Tidak Dipertimbangkan & 14 & 13 \\
& Kadang-Kadang Dipertimbangkan & 17 & 19 \\
& Sangat Dipertimbangkan & 113 & 103 \\
\multirow{3}{*}{ Se } & Tidak Dipertimbangkan & 67 & 63 \\
& Kadang-Kadang Dipertimbangkan & 31 & 33 \\
& Sangat Dipertimbangkan & 94 & 84 \\
So & Tidak Dipertimbangkan & 39 & 39 \\
& Kadang-Kadang Dipertimbangkan & 23 & 20 \\
& Sangat Dipertimbangkan & 34 & 32 \\
Ad & Tidak Dipertimbangkan & 49 & 45 \\
& Kadang-Kadang Dipertimbangkan & 17 & 23 \\
& Sangat Dipertimbangkan & 78 & 67 \\
Pe & Tidak Dipertimbangkan & 39 & 30 \\
& Kadang-Kadang Dipertimbangkan & 27 & 30 \\
& Sangat Dipertimbangkan & 126 & 120
\end{tabular}

Sumber: Data diolah

Hasil yang ditunjukkan Tabel 4 menunjukkan bahwa investor laki-laki menjawab sangat dipertimbangkan sebesar 64,06\% lebih besar dibandingkan investor perempuan sebesar $62,78 \%$ dari total jawaban variabel Ac (Accounting Information). Hasil ini menunjukkan bahwa investor laki-laki lebih memahami cara menganalisis laporan keuangan perusahaan yang merupakan hasil dari informasi akuntansi dibandingkan investor perempuan, jadi investor laki-laki lebih mempertimbangkan informasi akuntansi.

Tabel 5 berikut menyajikan hasil analisis crosstab antara variabel penelitian terhadap usia responden. 
Tabel 5. Analisis Crosstab Menurut Usia

\begin{tabular}{|c|c|c|c|c|c|c|}
\hline VARIABEL & KRITERIA & $<21$ & $21-30$ & $31-40$ & $41-50$ & $>50$ \\
\hline \multirow[t]{3}{*}{$\mathrm{Ne}$} & Tidak Dipertimbangkan & 11 & 21 & 0 & 0 & 0 \\
\hline & Kadang-Kadang Dipertimbangkan & 5 & 16 & 1 & 0 & 0 \\
\hline & Sangat Dipertimbangkan & 38 & 164 & 14 & 6 & 3 \\
\hline \multirow[t]{3}{*}{ Ac } & Tidak Dipertimbangkan & 19 & 59 & 2 & 3 & 0 \\
\hline & Kadang-Kadang Dipertimbangkan & 13 & 38 & 2 & 0 & 0 \\
\hline & Sangat Dipertimbangkan & 40 & 171 & 16 & 5 & 4 \\
\hline \multirow[t]{3}{*}{$\mathrm{Cl}$} & Tidak Dipertimbangkan & 13 & 13 & 1 & 0 & 0 \\
\hline & Kadang-Kadang Dipertimbangkan & 10 & 22 & 4 & 0 & 0 \\
\hline & Sangat Dipertimbangkan & 31 & 166 & 10 & 6 & 3 \\
\hline \multirow[t]{3}{*}{$\mathrm{Se}$} & Tidak Dipertimbangkan & 29 & 97 & 2 & 2 & 0 \\
\hline & Kadang-Kadang Dipertimbangkan & 13 & 44 & 6 & 1 & 0 \\
\hline & Sangat Dipertimbangkan & 30 & 127 & 12 & 5 & 4 \\
\hline \multirow[t]{3}{*}{ So } & Tidak Dipertimbangkan & 18 & 57 & 1 & 2 & 0 \\
\hline & Kadang-Kadang Dipertimbangkan & 7 & 30 & 6 & 0 & 0 \\
\hline & Sangat Dipertimbangkan & 11 & 47 & 3 & 2 & 2 \\
\hline \multirow[t]{3}{*}{ Ad } & Tidak Dipertimbangkan & 13 & 74 & 5 & 2 & 0 \\
\hline & Kadang-Kadang Dipertimbangkan & 15 & 20 & 5 & 0 & 0 \\
\hline & Sangat Dipertimbangkan & 26 & 107 & 5 & 4 & 3 \\
\hline \multirow[t]{3}{*}{$\mathrm{Pe}$} & Tidak Dipertimbangkan & 16 & 51 & 2 & 0 & 0 \\
\hline & Kadang-Kadang Dipertimbangkan & 12 & 39 & 6 & 0 & 0 \\
\hline & Sangat Dipertimbangkan & 44 & 178 & 12 & 8 & 4 \\
\hline
\end{tabular}

Sumber: Data diolah

Hasil yang disajikan Tabel 5 menunjukkan bahwa investor yang paling memperhatikan variabel Ac adalah investor yang berusia $>50$ tahun yaitu 100,00\%. Selanjutnya, investor yang berusia 31-40 sebesar $80,00 \%$; investor yang berusia $21-30$ sebesar $63,81 \%$; investor yang berusia 41-50 sebesar 62,50\%; dan investor yangb berusia <21 tahun sebesar 55,56\%. Apabila kita mengambil kesimpulan bahwa Investor yang berusia $>50$ merupakan investor yang paling mempertimbangkan variabel Ac, maka kesimpulan ini tidak akurat. Hal ini dikarenakan jumlah investor yang berusia $>50$ tahun hanya 1 orang. Pada bagian sebelumnya telah dijelaskan bahwa jumlah responden yang mayoritas adalah investor yang berusia 21-30 tahun. Hasil menunjukkan bahwa sebesar 63,81\% investor berusia 21-30 tahun telah mempertimbangkan variabel Ac (Accounting Information). Hasil Crosstab Usia terhadap Lama Menjadi Investor menunjukkan bahwa investor yang berusia 21-30 memiliki mayoritas berpengalaman dipasar modal 1-3 tahun. Jadi, investor usia 21-30 sudah memiliki bekal yang cukup dalam berpraktik berinvestasi di pasar modal dengan mengetahui cara analisis fundamental berupa penggunaan informasi akuntansi yaitu analisis laporan keuangan dan proyeksi kinerja keuangan perusahaan.

Tabel 6 akan menyajikan hasil analisis corsstab tingkat pendidikan responden terhadap variabel penelitian. 
Tabel 6. Analisis Crosstab Tingkat Pendidikan

\begin{tabular}{|c|c|c|c|c|c|c|c|}
\hline VARIABEL & KRITERIA & SD & SMP & SMA & S1 & $\mathrm{S} 2$ & $\mathrm{S3}$ \\
\hline \multirow[t]{3}{*}{$\mathrm{Ne}$} & Tidak Dipertimbangkan & 0 & 0 & 26 & 6 & 0 & 0 \\
\hline & $\begin{array}{l}\text { Kadang-Kadang } \\
\text { Dipertimbangkan }\end{array}$ & 0 & 0 & 6 & 13 & 3 & 0 \\
\hline & Sangat Dipertimbangkan & 0 & 0 & 76 & 134 & 10 & 0 \\
\hline \multirow[t]{3}{*}{ Ac } & Tidak Dipertimbangkan & 0 & 0 & 41 & 40 & 3 & 0 \\
\hline & $\begin{array}{l}\text { Kadang-Kadang } \\
\text { Dipertimbangkan }\end{array}$ & 0 & 0 & 20 & 26 & 7 & 0 \\
\hline & Sangat Dipertimbangkan & 0 & 0 & 83 & 138 & 15 & 0 \\
\hline \multirow[t]{3}{*}{$\mathrm{Cl}$} & Tidak Dipertimbangkan & 0 & 0 & 21 & 6 & 0 & 0 \\
\hline & $\begin{array}{l}\text { Kadang-Kadang } \\
\text { Dipertimbangkan }\end{array}$ & 0 & 0 & 11 & 18 & 7 & 0 \\
\hline & Sangat Dipertimbangkan & 0 & 0 & 76 & 129 & 11 & 0 \\
\hline \multirow[t]{3}{*}{ Se } & Tidak Dipertimbangkan & 0 & 0 & 73 & 55 & 2 & 0 \\
\hline & $\begin{array}{l}\text { Kadang-Kadang } \\
\text { Dipertimbangkan }\end{array}$ & 0 & 0 & 14 & 44 & 6 & 0 \\
\hline & Sangat Dipertimbangkan & 0 & 0 & 57 & 105 & 16 & 0 \\
\hline \multirow[t]{3}{*}{ So } & Tidak Dipertimbangkan & 0 & 0 & 41 & 35 & 2 & 0 \\
\hline & $\begin{array}{l}\text { Kadang-Kadang } \\
\text { Dipertimbangkan }\end{array}$ & 0 & 0 & 15 & 24 & 4 & 0 \\
\hline & Sangat Dipertimbangkan & 0 & 0 & 16 & 43 & 6 & 0 \\
\hline \multirow[t]{3}{*}{$\mathrm{Ad}$} & Tidak Dipertimbangkan & 0 & 0 & 35 & 53 & 6 & 0 \\
\hline & $\begin{array}{l}\text { Kadang-Kadang } \\
\text { Dipertimbangkan }\end{array}$ & 0 & 0 & 8 & 25 & 7 & 0 \\
\hline & Sangat Dipertimbangkan & 0 & 0 & 65 & 75 & 5 & 0 \\
\hline \multirow[t]{3}{*}{$\mathrm{Pe}$} & Tidak Dipertimbangkan & 0 & 0 & 40 & 28 & 1 & 0 \\
\hline & $\begin{array}{l}\text { Kadang-Kadang } \\
\text { Dipertimbangkan }\end{array}$ & 0 & 0 & 21 & 26 & 10 & 0 \\
\hline & Sangat Dipertimbangkan & 0 & 0 & 83 & 150 & 13 & 0 \\
\hline
\end{tabular}

Sumber: Data diolah

Hasil pada Tabel 6 menyajikan bahwa investor dengan tingkat pendidikan S1 lebih mempertimbangkan Ac dalam mengambil keputusan investasi dengan proporsi 67,65\% jawaban sangat dipertimbangkan. Investor dengan tingkat pendidikan S2 hanya memiliki proporsi $60,00 \%$ jawaban sangat dipertimbangkan. Investor dengan tingkat pendidikan SMA hanya memiliki proporsi $57,64 \%$ jawaban sangat dipertimbangkan. Hasil ini bertolak belakang dengan pernyataan (Christanti et al., 2011) yang menyatakan banyak diyakini investor yang memiliki tingkat pendidikan lebih tinggi akan lebih baik dalam mengambil keputusan dalam berinvestasi. Hal ini karena mayoritas responden dalam penelitian ini bertingkat pendidikan S1 yaitu sebanyak 51. Investor yang memiliki tingkat pendidikan S1 akan berusia pada kisaran 21-30 tahun yang merupakan investor milenial. Investor milenial memiliki ketertarikan untuk belajar berinvestasi di pasar modal lebih besar dibandingkan investor yang memiliki tingkat pendidikan SMA, S2 dan S3. Sehingga investor yang memiliki tingkat pendidikan S1 akan lebih giat dalam mengikuti seminar-seminar di dunia pasar modal. Ilmu mengenai analisis fundamental dan teknikal yang didapatkan investor bertingkat pendidikan S1 akan diterapkan secara teknis (langsung dipraktikkan) dalam bentuk investasi di pasar modal. 
Tabel 7 akan menyajikan hasil analisis crosstab lama menjadi investor terhadap variabel penelitian.

Tabel 7. Analisis Crosstab Lama Menjadi Investor

\begin{tabular}{|c|c|c|c|c|c|}
\hline VARIABEL & KRITERIA & $<1$ & $1-3$ & $4-6$ & $>6$ \\
\hline \multirow[t]{3}{*}{$\mathrm{Ne}$} & Tidak Dipertimbangkan & 5 & 27 & 0 & 0 \\
\hline & Kadang-Kadang Dipertimbangkan & 7 & 13 & 1 & 0 \\
\hline & Sangat Dipertimbangkan & 32 & 143 & 47 & 3 \\
\hline \multirow[t]{3}{*}{ Ac } & Tidak Dipertimbangkan & 10 & 58 & 13 & 2 \\
\hline & Kadang-Kadang Dipertimbangkan & 20 & 29 & 4 & 0 \\
\hline & Sangat Dipertimbangkan & 30 & 157 & 47 & 2 \\
\hline \multirow[t]{3}{*}{$\mathrm{Cl}$} & Tidak Dipertimbangkan & 11 & 15 & 1 & 0 \\
\hline & Kadang-Kadang Dipertimbangkan & 15 & 20 & 1 & 0 \\
\hline & Sangat Dipertimbangkan & 19 & 148 & 46 & 3 \\
\hline \multirow[t]{3}{*}{ Se } & Tidak Dipertimbangkan & 20 & 97 & 11 & 2 \\
\hline & Kadang-Kadang Dipertimbangkan & 13 & 38 & 13 & 0 \\
\hline & Sangat Dipertimbangkan & 27 & 109 & 40 & 2 \\
\hline \multirow[t]{3}{*}{ So } & Tidak Dipertimbangkan & 13 & 57 & 7 & 1 \\
\hline & Kadang-Kadang Dipertimbangkan & 9 & 27 & 7 & 0 \\
\hline & Sangat Dipertimbangkan & 8 & 38 & 18 & 1 \\
\hline \multirow[t]{3}{*}{$\mathrm{Ad}$} & Tidak Dipertimbangkan & 11 & 59 & 23 & 1 \\
\hline & Kadang-Kadang Dipertimbangkan & 17 & 21 & 2 & 0 \\
\hline & Sangat Dipertimbangkan & 17 & 103 & 23 & 2 \\
\hline \multirow[t]{3}{*}{$\mathrm{Pe}$} & Tidak Dipertimbangkan & 11 & 54 & 4 & 0 \\
\hline & Kadang-Kadang Dipertimbangkan & 14 & 39 & 4 & 0 \\
\hline & Sangat Dipertimbangkan & 35 & 151 & 56 & 4 \\
\hline
\end{tabular}

Hasil yang disajikan Tabel 7 menunjukkan bahwa Variabel Ac (Accounting Information) paling dipertimbangkan oleh investor yang memiliki pengalaman berinvestasi 4-6 tahun yaitu sebesar $73,44 \%$ dari total jawaban variabel Ac. Hal ini menunjukkan bahwa pengalaman investor 4-6 tahun sudah cukup untuk membentuk seorang investor yang rasional dengan mempertimbangkan informasi akuntansi sebagai landasan dalam mengambil keputusan berinvestasi di pasar modal. Informasi akuntansi terkandung di dalam laporan keuangan perusahaan. Hasil analisis dari laporan keuangan inilah yang disebut dengan analisis fundamental perusahaan. Untuk menjadi investor sejati, maka harus mengetahui cara analisis fundamental yang baik dan benar (Mahmood et al., 2011).

Tabel 8 akan menyajikan hasil analisis crosstab agama terhadap variabel penelitian $\mathrm{Ne}$ (Neutral Information), Ac (Accounting Information), Cl (Classic), Se (Self Image/Firm-Image Coincidence), So (Social Relevance), Ad (Advocate Recommendation), dan Pe (Personal Financial Need). 
Tabel 8. Analisis Crosstab Agama

\begin{tabular}{|c|c|c|c|c|c|c|c|}
\hline VARIABEL & KRITERIA & Islam & Kristen & Katolik & Hindu & Budha & Lainnya \\
\hline \multirow[t]{4}{*}{$\mathrm{Ne}$} & Tidak Dipertimbangkan & 32 & 0 & 0 & 0 & 0 & 0 \\
\hline & Kadang-Kadang & & & & & & \\
\hline & Dipertimbangkan & 22 & 0 & 0 & 0 & 0 & 0 \\
\hline & Sangat Dipertimbangkan & 225 & 0 & 0 & 0 & 0 & 0 \\
\hline \multirow[t]{4}{*}{ Ac } & Tidak Dipertimbangkan & 83 & 0 & 0 & 0 & 0 & 0 \\
\hline & Kadang-Kadang & & & & & & \\
\hline & Dipertimbangkan & 53 & 0 & 0 & 0 & 0 & 0 \\
\hline & Sangat Dipertimbangkan & 236 & 0 & 0 & 0 & 0 & 0 \\
\hline \multirow[t]{4}{*}{$\mathrm{Cl}$} & Tidak Dipertimbangkan & 27 & 0 & 0 & 0 & 0 & 0 \\
\hline & Kadang-Kadang & & & & & & \\
\hline & Dipertimbangkan & 36 & 0 & 0 & 0 & 0 & 0 \\
\hline & Sangat Dipertimbangkan & 216 & 0 & 0 & 0 & 0 & 0 \\
\hline \multirow[t]{4}{*}{ Se } & Tidak Dipertimbangkan & 130 & 0 & 0 & 0 & 0 & 0 \\
\hline & Kadang-Kadang & & & & & & \\
\hline & Dipertimbangkan & 64 & 0 & 0 & 0 & 0 & 0 \\
\hline & Sangat Dipertimbangkan & 178 & 0 & 0 & 0 & 0 & 0 \\
\hline \multirow[t]{4}{*}{ So } & Tidak Dipertimbangkan & 78 & 0 & 0 & 0 & 0 & 0 \\
\hline & Kadang-Kadang & & & & & & \\
\hline & Dipertimbangkan & 43 & 0 & 0 & 0 & 0 & 0 \\
\hline & Sangat Dipertimbangkan & 65 & 0 & 0 & 0 & 0 & 0 \\
\hline \multirow[t]{4}{*}{$\mathrm{Ad}$} & Tidak Dipertimbangkan & 94 & 0 & 0 & 0 & 0 & 0 \\
\hline & Kadang-Kadang & & & & & & \\
\hline & Dipertimbangkan & 40 & 0 & 0 & 0 & 0 & 0 \\
\hline & Sangat Dipertimbangkan & 145 & 0 & 0 & 0 & 0 & 0 \\
\hline \multirow[t]{4}{*}{$\mathrm{Pe}$} & Tidak Dipertimbangkan & 69 & 0 & 0 & 0 & 0 & 0 \\
\hline & Kadang-Kadang & & & & & & \\
\hline & Dipertimbangkan & 57 & 0 & 0 & 0 & 0 & 0 \\
\hline & Sangat Dipertimbangkan & 246 & 0 & 0 & 0 & 0 & 0 \\
\hline
\end{tabular}

Sumber: Data diolah

Hasil yang disajikan Tabel 8 menunjukkan bahwa Variabel Ac (Accounting Information) memiliki persentase sebesar 63,44\%. Persentase tersebut tergolong besar, karena persentase lebih dari 50\% menunjukkan variabel Ac sangat dipertimbangkan oleh investor dalam mengambil keputusan investasinya. Hasil ini menunjukkan bahwa investor beragama islam memiliki rasionalitas yang cukup tinggi dalam mengambil keputusan investasnya. Investor beragama islam rata-rata tidak hanya bertujuan mendapatkan keuntungan dalam kegiatan investasinya, tetapi lebih pada dasar dalam membeli suatu saham. Sebuah landasan dalam pengambulan keputusan membeli suatu saham akan menghindarkan investor dari hukum "judi". Pada ajaran agama islam telah sangat dilarang untuk melaksanakan "judi”. Allah berfirman dalam Surat Al Maidah: 90, yang artinya:

"Hai orang-orang yang beriman, sesungguhnya (meminum) khamar, berjudi, (berkorban untuk) berhala, mengundi nasib dengan panah, adalah termasuk perbuatan syaitan. Maka jauhilah perbuatan-perbuatan itu agar kamu mendapat keberuntungan" (QS. Al Maidah: 90).

Saham perusahaan yang dibeli tanpa menganalisis keadaan kinerja perusahaan tersebut merupakan perbuatan untung-untungan yang hanya sekedar memperhatikan rumor berita dan hasutan orang lain untuk bersama-sama membeli saham tersebut akan sama dengan perbuatan judi yang pada dasarnya mengundi nasib. Perbuatan ini merupakan 
ajakan setan dan balasannya adalah neraka bagi yang melakukan judi. Hal ini tersurat dalam Surat Fatir: 6, yang artinya:

"Sesungguhnya syaitan itu adalah musuh bagimu, maka anggaplah ia musuh(mu), karena sesungguhnya syaitan-syaitan itu hanya mengajak golongannya supaya mereka menjadi penghuni neraka yang menyala-nyala" (QS. Fathir: 6).

Ketika investor memiliki landasan yang kuat dalam membeli suatu saham, maka dia akan terhindar dari perbuatan judi. Pertimbangan yang matang dengan menganalisis fundamental dan teknikal suatu saham akan menumbuhkan tujuan investasi yang benar, yaitu tujuan jangka panjang sebagai lindung nilai aset pribadi.

\section{KESIMPULAN}

Hasil analisis menunjukkan bahwa peringkat pertama dalam kasus sangat dipertimbangan investor dalam mengambil keputusan investasi adalah Analisis terhadap laporan keuangan perusahaan saat ini yang dijawab oleh 86 (92,47\%) investor. Indikator Analisis terhadap laporan keuangan perusahaan saat ini adalah indikator dari Variable Accounting Information (Ac). Hasil ini membuktikan bahwa pada analisis karakteristik responden yang telah dibahas bahwa responden terbanyak terdiri dari para investor yang beragama islam. Investor beragama islam sudah pasti akan berpikir rasional dan mempertimbangkan kinerja keuangan perusahaan sebagai landasan untuk melakukan investasi.

Analisis variabel Ac ditemukan bahwa Investor yang terdaftar di GI BEI Universitas Muhammadiyah Jember lebih mempertimbangkan Accounting Information atau Informasi Akuntansi dibandingkan dengan Investor yang terdaftar di GI BEI STIE Mandala Jember dan GI BEI Universitas Jember. Investor laki-laki lebih memahami cara menganalisis laporan keuangan perusahaan yang merupakan hasil dari informasi akuntansi dibandingkan investor perempuan, jadi investor laki-laki lebih mempertimbangkan informasi akuntansi. Investor berusia 21-30 tahun memiliki proporsi sebesar sangat dipertimbangkan sebesar 63,81\%. Investor dengan tingkat pendidikan S1 lebih mempertimbangkan Ac dalam mengambil keputusan investasi dengan proporsi $67,65 \%$ jawaban sangat dipertimbangkan. Investor yang memiliki pengalaman berinvestasi 4-6 tahun lebih mempertimbangkan Ac. Investor islami memiliki proporsi sebesar 63,44\% mempertimbangkan variabel Ac.

Penelitian ini memiliki implikasi bagi beberapa pihak. Penelitian ini memberikan manfaat kepada akademisi dalam hal pengembangan ilmu pengetahuan mengenai landasan pengambilan keputusan investasi khususnya pemanfaatan Accounting Information bagi investor islami. Penelitian ini memberikan manfaat kepada investor dalam hal penguatan landasan dalam pengambilan keputusan investasi khususnya pemanfaatan Accounting Information bagi investor islami. Penelitian ini memberikan gambaran mengenai keadaan investor khususnya yang berada di kawasan Kabupaten Jember mengenai preferensi landasan dalam pengambilan keputusan investasi khususnya pemanfaatan Accounting Information bagi investor islami. Sehingga pihak Bursa Efek Indonesia dapat memberikan ilmu pengetahuan berupa workshop/seminar mengenai preferensi landasan pengambilan keputusan investasi berupa pemanfaatan Accounting Information.

Penelitian ini memiliki beberapa keterbatasan. Keterbatasan penelitian yang pertama yaitu karakteristik responden penelitian belum merata, karena jumlah responden menurut demografinya dalam penelitian ini masih terlalu ketimpang jauh, baik itu berdasarkan tempat investor terdaftar, jenis kelamin, usia, lama berinvestasi, tingkat pendidikan dan agama. Selain itu, alat analisis dalam penelitian ini masih sangat sederhana dengan hanya menggunakan analisis distribusi frekuensi dan crosstab. Sedangkan ketrebatasan penelitian yang terakhir yaitu uji data dihasilkan kurang reliabel, tetapi karena penelitian ini menganalisis mengenai pendapat investor yang menjadi dasar pengambilan keputusan 
invstasi jadi menghasilkan jawaban yang beraneka ragam. Oleh karena itu, wajar ketika hasil uji relibailitas mengahasilkan data yang kurang reliabel.

\section{DAFTAR PUSTAKA}

Al-Tamimi, H. A. H. (2014). Factors Influencing Individual Investor Behaviour: An Empirical study of the UAE Financial Markets, The Business Review, Cambridge, Vol . 5, No . 2, 225-232 ,. 5(2), 225-232.

Christanti, N., Ariany Mahastanti, L., \& Ekonomika dan Bisnis Unversitas Kristen Satya Wacana, F. (2011). Faktor-Faktor Yang Dipertimbangkan Investor Dalam Melakukan Investasi. Jurnal Manajemen Teori Dan Terapan | Tahun, 4(3), 37-51.

Dewan Syariah Nasional MUI No. 40 Tahun 2003.

El-Qurtubi, Usman. 2015. Al-Qur'an Cordoba Terjemahan dan Tajwid Berwarna. Bandung: Cordoba International - Indonesia.

Ghozali, I. (2016). Aplikasi Analisis Multivariate dengan Program IBM SPSS 21 :Update PLS Regresi. Semarang. https://doi.org/10.2307/1579941

https://market.bisnis.com/read/20181227/7/873383/ksei-jumlah-investor-pasar-modal-tumbuh44-sepanjang-2018 accessed December 5, 2019.

Mahmood, I., Ahmad, H., Khan, A. Z., \& Anjum, M. (2011). Behavioral implications of investors for investments in the stock market. European Journal of Social Sciences.

Merikas, A. A., Merikas, A. G., Vozikis, G. S., \& Prasad, D. (2011). Economic Factors And Individual Investor Behavior: The Case Of The Greek Stock Exchange. Journal of Applied Business Research (JABR), 20(4), 93-98. https://doi.org/10.19030/jabr.v20i4.2227

Obamuyi, T. M. (2013). Factors Influencing Investment Decisions in Capital Market: a Study of Individual Investors in Nigeria. Organizations and Markets in Emerging Economies, 4(1), 141161. https://doi.org/10.15388/omee.2013.4.1.14263

Nagy R, Obenberger R. 1994. Factors Influencing Individual Investor Behaviorll. Financial Analyst Journal, Vol.50. No.4 63-68. 